\title{
DYNAMICS OF INCIDENCE AND FREQUENCY OF POPULATIONS OF Fusarium SPECIES ON STORED MAIZE GRAIN**
}

\section{Krnjaja ${ }^{1 *}$, J. Lević ${ }^{2}$, Z. Tomić ${ }^{1}$, Z. Nešić ${ }^{1}$, Lj. Stojanović ${ }^{1}$, S. Trenkovski ${ }^{1}$}

${ }^{1}$ Institute for Animal Husbandry, Belgrade-Zemun, 11080, Republic of Serbia

${ }^{2}$ Maize Research Institute "Zemun Polje“, Belgrade-Zemun, 11080, Republic of Serbia

*Corresponding author, e-mail:VesnaKrnjaja.IZS@gmail.com

** Original scientific paper. The paper is financed by Ministry of Science of the Republic of Serbia project No. TR-6826B

\begin{abstract}
Production and providing of high quality maize grain are of primary importance for livestock production since maize is the main component of livestock feed. Contamination with fungi not only diminishes the quality of grain, but some fungi species can produce highly toxic compounds known as mycotoxins. Considering that maize is economically the most important grown plant in Serbia, content and intensity of frequency of these pathogen fungi species are investigated in maize stored in the storage facilities.

Based on studies of the fungi incidence in stored maize intended for nutrition of livestock, it was established that during the period from February 2005 to March 2006, some fungi species were present successively (Fusarium spp., Penicillium spp.), other with interruptions of one (Nigrospora spp., Aspergillus spp., Acremonium spp., Alternaria spp), three (Mucor spp., Chaetomium spp., Rhizopus spp.) to four months (Cladosporium spp.), and also sporadically during three (Epicoccum spp., Rhizopus spp., Trichothecium spp.), two (Gliocladium spp.) or one month (Papulaspora spp., Phialophora spp.). Period June-October is the most critical for preservation of the quality of stored maize since the number of fungi species present (8-14 of total of 17 identified fungi genera) and their frequency during this period are the highest, especially of toxigenic species of Fusarium (43.5-62.5\%) and Penicillium (10.0-33.5\%) genera. Positive correlation $\left(\mathrm{r}=0.5979^{* *}\right)$ between dynamics of incidence and frequency of isolated fungi species indicates that fungi with higher frequency of incidence remain longer on the grain during storage.
\end{abstract}


F. verticillioides and F. subglutinans, of total of 6 identified Fusarium species were present on the grain during entire year and with the highest frequency $(24.7 \%$ and $5.9 \%$, respectively). During single year (2005) $F$. verticillioides was present in the highest percentage from February to October (22.0-39.5\%), and F. subglutinans from April to October $(8.0-12.5 \%)$, whereas the both species were isolated the least during winter period December-January $(4.0-8.0 \%$ and $0.5-1.0 \%$, respectively). $F$. graminearaum is the third toxigenic Fusarium species which from the mycotoxicological aspect can be important for period June-September when it is mostly present (5.0-11.0\%). Incidence of other Fusarium species is sporadic $(1.3 \% F$. proliferatum, $1.0 \% F$. sambucinum and $0.5 \% F$. poae).

Key words: maize, grain, stored mycopopulation, Fusarium species, dynamics

\section{Introduction}

Maize (Zea mays L.) is one of the most important cultivated crops in Serbia grown on approximately 1,2 million ha (Statistical Yearbook of Serbia, 2001). This crop is mainly used as feed or as a component of livestock feed especially for pigs and poultry (Lazarević et al., 1998). The production and supply of high quality maize grain remains of prime importance in Serbia. Cereals must thus be protected in the field against disease and in storages after harvest against fungal attack. Invasion by fungi not only reduces the quality of the grain but some species of moulds can produce highly toxic compounds known as mycotoxins (Marasas et al., 1984). Due to it and to the fact that maize is economically the most important cultivated plant in Serbia, a composition and the intensity of the incidence of these pathogenic fungal species are observed in stored maize grain.

Determining ear mould problems prior to harvest is critical to managing and minimizing the impact of these diseases through timely harvest and proper drying/storage conditions. It is also important to identify which ear moulds are present since not all of these fungi produce toxins. Fusarium species are the most economically important causal agents reported worldwide as responsible for ear rot (White, 2000; Tenuta, 2006).

In Brazil, the species of the genus Fusarium were mostly distributed $(83.8 \%)$ in maize grain sampled both, after harvest and in storages (Pozzi et 
al., 1995). These species were followed by Penicillium spp. (55.3\%), Aspergillus spp. (40.7\%), Cladosporium spp. (32.3\%), then by yeasts (19.2\%), Mycelia sterilia (10.7\%), Rhizopus spp. (9.2\%), Mucor spp. (7.7\%), Absidia spp. (2.3\%), Wallemia spp. (2.3\%), Trichoderma spp. (0.7\%), Paecilomyces spp. (0.7\%), Neurospora spp. (0.7\%), Alternaria $(0.7 \%)$ and Aureobasidium spp. (0.7\%).

According to Pozzi et al. (1995) Fusarium verticillioides was the most dominant species $(80.7 \%)$, while $F$. proliferatum ranked second $(3.0 \%)$. According to Marasas (1991), F. verticillioides occurs worldwide and is one of the most prevalent fungi associated with corn in most of the cornproducing areas. Marasas et al. (1979) revealed that the mean percentage of kernel infection by fungi increased during 8 months of commercial storage in temperature, subtropical, and intermediate areas of South Africa.

The Fusaria frequently isolated from maize in Mediterranean countries are widespread $F$. verticillioides and $F$. graminerarum (Logrieco et al., 1995). Fusarium species commonly isolated from Mediterranean cereals produce high amounts of fumonisin $\mathrm{FB}_{1}$ and zearalenone (ZEN) in vitro on different media. A study of $\mathrm{FB}_{1}$ production by 28 strains of $F$. verticillioides isolated from cereals in Italy, Spain and France revealed fumonisinotoxigenic potential for all strains with maximum produced concentration of $4100 \mathrm{mg} \mathrm{kg}^{-1}$ (Visconti, 1994).

The obtained results in the period 1994-1996 by Lević et al. (1997) indicate that $F$. verticillioides $(63.0 \%)$ is predominant maize ear rot in Serbia, followed by the $F$. subglutinans $(50,6 \%), F$. graminearum $(12.2 \%)$, $F$. proliferatum $(9.6 \%)$ and $F$. oxysporum $(5.8 \%)$. According to these authors $F$. solani occurred each year, but is frequency was not so high $(2.4 \%)$, and other Fusarium species ( $F$. equiseti, F. sporotrichiodes, $F$. chlamydosporum, $F$. crookwellense and $F$. semitectum) occurred sporadically on a few number of samples.

Some of the fungi associated with grain in the field (often referred to as "field fungi") can form mycotoxins, such as Fusarium, Aspergillus and Penicillium, either immediately before, or just after harvest (Hocking, 2003). Fungal contamination in storage can also be related to levels in the field (Hell et al., 2003). Mycotoxin contamination of grain is not always a result of poor storage, as some mycotoxins, particularly Fusarium toxins, may already be in the grains when they are brought into storage. However, if moulds do start to grow in stored grains, mycotoxins may be formed if the fungal succession develops to a point where mycotoxigenic species are able to grow. Whether or not mycotoxins are an issue, any mould development in 
stored grains is undesirable (Hocking, 2003).

Globally, it is considered that following species of Fusarium genus are the most toxigenic $F$. sporotrichioides, $F$. graminearum and $F$. verticillioides since their mycotoxins can cause serious diseases in animals and humans (Marasas, 2000; Marasas et al., 1984). In agro ecological conditions of Serbia $F$. graminearum is mainly studied as toxigenic species (BočarovStančić, 1996), although also $F$. verticillioides and $F$. subglutinans can be considered as species which most frequently cause fusariosis of maize grain (Lević et al., 1997). In Serbia, two epidemics of mycotoxicosis in livestock were registered in the years when fusariosis of the maize ear was progressing in epidemic proportions, such was the case in years 1968 or 1972 and in subsequent years when this maize was used in livestock nutrition (Marić, 2002). Based on expressed disease symptoms in domestic animals (vulvovaginitis, refusal of feed in pigs) in years of maize ear fusariosis epidemics it can be concluded that maize was contaminated with zearalenone and trihothecenes.

Because of extraordinary importance of use of healthy feed in livestock production, in this paper, the dynamics of incidence and intensity of presence of potentially toxigenic fungi species during longer time period were investigated, especially of Fusarium genus, and on stored maize grain intended for livestock nutrition.

\section{Material and methods}

A total of 28 samples of stored maize originated from around Belgrade were used in this study. Stored grains of maize $(1000 \mathrm{~g})$ were collected from each monthly twice during period of 14 months, i.e. from February 2005 to March 2006. The average grain moisture in collected samples amounted $12.7 \%$.

Sub samples (100 kernels) were rinsed under running tap water for 1 hour. Then, kernels were superficially disinfected in $5 \% \mathrm{NaOCl}$ and rinsed three times with sterile distilled water for 5 minutes. Kernels were dried on the filter paper and placed on the $2 \%$ agar medium in $10-\mathrm{cm}$ Petri dishes. These kernels were incubated in the thermostat at the temperature of $26^{\circ} \mathrm{C}$. Six days later, the identification of fungal colonies, especially of those of the genus Fusarium, developed in the area around incubated maize kernels was carried out by the microscopic examination.

The identification of Fusarium species on the basis of morphological macroscopic and microscopic characteristics on potato-dextrose agar (PDA) 
and synthetic nutrient agar (SNA) was done after Nelson et al., (1983) and Burgess et al. (1994), while remaining fungal genera were determined after Ellis (1971) and Watanabe et al. (1994).

Data obtained for dynamics (number of months) and intensity of fungi incidence on stored maize grain during the period from February 2005 to March 2006 (14 months) were used for calculation of correlation coefficient. Significance of interrelations of these two factors was tested at the level of $\mathrm{P}_{0.05}$ and $\mathrm{P}_{0.01}$.

\section{Results and discussion}

Based on study of dynamics of incidence of certain species of fungi during storage in period from February 2005 to March 2006 (table 1), they can be divided into three groups with traits: (1) successive incidence throughout the year (Fusarium spp., Penicillium spp.); (2) discontinuous incidence: not identified in one (Nigrospora spp., Aspergillus spp., Acremonium spp., Alternaria spp), three (Mucor spp., Chaetomium spp., Rhizopus spp.) or four months (Cladosporium spp.); (3) sporadic incidence: determined only during three (Rhizopus spp., Epicoccum spp., Trichothecium spp.), two (Gliocladium spp.) to one month (Papulaspora spp., Phialophora spp.).

Of total 17 fungi genera, determined on stored maize grain from February 2005 to March 2006, 7 (May 2006) to 11 (February, June and December 2005 and January 2006) were always present, and only 14 in September and 12 in October 2006 (table 1).

Species of genera Fusarium and Penicillium are always present, in average 33.6 and $21.7 \%$, respectively. During 2005, presence of Fusarium spp. varied from $4,5 \%$ (December) to $62.5 \%$ (July)in2005, and they were the most frequent in period from April (52.0\%) to October (45.0\%). Penicillium species on stored maize corn were most frequent in March (43.0\%), April (29.0\%), May (28.0\%) and October (33.5\%), whereas in other months their presence varied from $10.0 \%$ (July 2005) to $25.5 \%$ (December 2005 and February 2006). Species of Nigrospora, Aspergillus, Acremonium and Alternaria were determined in 13 of 14 months in average $11.2 \%, 7.0 \%$, $6.3 \%$ and $4.0 \%$, respectively. Nigrospora spp. was approximately equally frequent in April (18.0\%), May (19.5\%), June (19.0\%) and August (19.5\%), whereas Aspergillus spp. was the most frequent in March $(24.0 \%)$, Acremonium spp. in October (18.5\%) and Alternaria spp. in August (18.0\%). 
On stored maize grain, also, frequent is incidence of genera Mucor, Chaetomium and Rhizopus (11 months), as well as Cladosporium (10 months), but in average of considerably lower intensity $(5.7 \%, 4.8 \%, 1.9 \%$ and $3.3 \%$, respectively) than previous species. Except species of genus Trichoderma, which were determined in discontinuity over 6 months, other fungi genera were determined only in three (Epicoccum spp., Trichotecium spp. Dreschlera spp.), two (Gliocladium spp.) or one month (Papulospora spp. and Phialophora spp.) on stored maize grain. Considerable was also presence of Chaetomium (11.5\%) and Cladosporium (13.0\%) species during September 2005 and Trichoderma spp. (11.0\%) in March 2006.

Species of Fusarium genus were most present in July (62.5\%) 2005, and the least in December (4.5\%) 2005. Of six identified species of Fusarium genus in all investigated months, $F$. verticillioides and $F$. subglutinans were determined with intensity of $4.0-39.5 \%$ and $0.5-12.5 \%$ or in average $24.7 \%$ and $5.9 \%$, respectively (table 2 ). In investigation period, $F$. verticillioides was very highly present in April (39.5\%), May (34.5\%), June (33.0\%), July $(39.0 \%)$, August $(32.0 \%)$ and October $(34.5 \%)$ of 2005 , and the lowest presence was in December (4.0\%) of 2005. Presence of $F$. subglutinans in most of the months of investigation was low (0.5-4.5\%) and relatively high (5.0-8.5\%), except in April, May and July 2005, when it's presence was very high (10.0-12.5\%). During 14 months, discontinuous presence of $F$. graminearum during 7 months, $0,5 \%$ (November 2005) to $11 \%$ (September 2005 ) or in average $5.0 \%$ was established. Other species ( $F$. proliferatum, $F$. sambucinum and $F$. poae) were determined sporadically (4, 2 or 1 months) and in poor intensity $(0,5-1.3 \%)$.

Analysis of results obtained for contamination with fungi of maize grain stored in warehouses, which was intended for livestock nutrition, shows that in the period February - March there were differences between investigation years in regard to incidence of certain species as well as their intensity (Tables 1,2).

Based on PPU parameters (table 1) positive correlation $(\mathrm{r}=0.5979 * *)$ between dynamics of incidence (number of months during which the presence of species was determined) and frequency of fungi (\%) on stored maize grain during storage from February 2005 to March 2006 was established. 
Table 1. Dynamics of fungi occurrence and frequency (\%) on maize storage in the period of February 2005 to March 2006

\begin{tabular}{|c|c|c|c|c|c|c|c|c|c|c|c|c|c|c|c|}
\hline \multirow{3}{*}{ Fungal species } & \multicolumn{14}{|c|}{ Month of investigation $^{\mathrm{a}}$} & \multirow{3}{*}{$\mathrm{PPU}^{\mathrm{b}}$} \\
\hline & \multicolumn{11}{|c|}{2005} & \multicolumn{3}{|c|}{2006} & \\
\hline & $\mathrm{F}$ & $\mathrm{M}$ & $\mathrm{A}$ & $\mathrm{M}$ & $\mathrm{J}$ & $\mathrm{J}$ & $\mathrm{A}$ & $\mathrm{S}$ & $\mathrm{O}$ & $\mathrm{N}$ & $\mathrm{D}$ & $\mathrm{J}$ & $\mathrm{F}$ & $\mathrm{M}$ & \\
\hline Fusarium spp. & 39.0 & 27.5 & 52.0 & 44.5 & 48.0 & 62.5 & 43.5 & 48.0 & 45.0 & 13.0 & 4.5 & 9.0 & 13.0 & 17.5 & $14 / 33.6$ \\
\hline Penicillium spp. & 10.5 & 43.0 & 29.0 & 28.0 & 14.5 & 10.0 & 16.0 & 15.5 & 33.5 & 17.0 & 25.5 & 16.5 & 25.5 & 19.0 & $14 / 21.7$ \\
\hline Nigrospora spp. & 5.5 & 14.5 & 18.0 & 19.5 & 19.0 & 7.5 & 19.5 & 11.0 & 0.0 & 1.0 & 8.5 & 7.0 & 11.0 & 4.0 & $13 / 11.2$ \\
\hline Aspergillus spp. & 3.5 & 24.0 & 9.0 & 2.0 & 5.0 & 0.0 & 2.5 & 1.5 & 13.5 & 9.0 & 1.0 & 3.0 & 7.5 & 9.0 & $13 / 7.0$ \\
\hline Acremonium spp. & 12.5 & 5.5 & 8.5 & 12.5 & 4.0 & 9.0 & 2.5 & 1.0 & 18.5 & 2.5 & 0.0 & 3.5 & 1.5 & 1.0 & $13 / 6.3$ \\
\hline Mucor spp. & 0.5 & 4.0 & 8.5 & 0.0 & 0.0 & 0.0 & 2.0 & 4.5 & 0.5 & 10.5 & 13.0 & 12.5 & 0.5 & 6.0 & $11 / 5.7$ \\
\hline Alternaria spp. & 2.5 & 1.0 & 2.0 & 0.0 & 3.5 & 7.0 & 18.0 & 4.5 & 1.5 & 4.0 & 5.0 & 1.0 & 1.0 & 1.5 & $13 / 4.0$ \\
\hline Chaetomium spp. & 0.0 & 0.0 & 0.0 & 2.0 & 2.0 & 2.0 & 3.5 & 11.5 & 2.0 & 2.0 & 4.0 & 10.5 & 4.0 & 10.0 & $11 / 4.8$ \\
\hline Cladosporium spp. & 1.5 & 0.5 & 0.0 & 0.0 & 0.0 & 3.5 & 8.0 & 13.0 & 0.5 & 2.5 & 1.5 & 1.0 & 0.5 & 0.0 & $10 / 3.3$ \\
\hline Trichoderma spp. & 0.0 & 0.0 & 2.5 & 0.0 & 7.5 & 0.0 & 0.0 & 0.5 & 4.5 & 0.0 & 0.0 & 0.0 & 3.0 & 11.0 & $6 / 4.8$ \\
\hline Rhizopus spp. & 4.0 & 1.5 & 2.0 & 0.5 & 0.5 & 0.5 & 1.0 & 3.0 & 3.0 & 0.0 & 2.5 & 2.5 & 0.0 & 0.0 & $11 / 1.9$ \\
\hline Epicoccum spp. & 0.9 & 0.0 & 0.0 & 0.0 & 0.0 & 0.0 & 0.0 & 0.0 & 1.5 & 1.5 & 0.5 & 0.0 & 0.0 & 0.0 & $3 / 1.2$ \\
\hline Trichotecium spp. & 0.0 & 0.0 & 0.0 & 0.0 & 0.0 & 0.0 & 0.0 & 1.5 & 0.5 & 0.0 & 0.0 & 1.0 & 0.0 & 0.0 & $3 / 1.0$ \\
\hline Dreschlera spp. & 0.0 & 0.0 & 0.5 & 0.0 & 1.0 & 0.0 & 0.0 & 0.0 & 0.0 & 0.0 & 0.5 & 0.0 & 0.0 & 0.0 & $3 / 0.7$ \\
\hline Gliocladium spp. & 1.0 & 0.0 & 0.0 & 0.0 & 1.0 & 0.0 & 0.0 & 0.0 & 0.0 & 0.0 & 0.0 & 0.0 & 0.0 & 0.0 & $2 / 1.0$ \\
\hline Papulaspora spp. & 0.0 & 0.0 & 0.0 & 0.0 & 0.0 & 0.0 & 0.0 & 2.0 & 0.0 & 0.0 & 0.0 & 0.0 & 0.0 & 0.0 & $1 / 2.0$ \\
\hline Phialophora spp. & 0.0 & 0.0 & 0.0 & 0.0 & 0.0 & 0.0 & 0.0 & 2.0 & 0.0 & 0.0 & 0.0 & 0.0 & 0.0 & 0.0 & $1 / 2.0$ \\
\hline
\end{tabular}

${ }^{\mathrm{a}}$ First letter of month when the phytopathological analysis of maize sample stored in the period of February 2005 to March 2006 was carried out.

${ }^{b}$ Number of positive samples of total 14/Average for positive samples

Table 2. Dynamics of Fusarium species occurrence and frequency (\%) on maize storage in the period of February 2005 to March 2006

\begin{tabular}{|c|c|c|c|c|c|c|c|c|c|c|c|c|c|c|c|}
\hline \multirow{3}{*}{ Fusarium species } & \multicolumn{14}{|c|}{ Month of investigation ${ }^{\mathrm{a}}$} & \multirow{3}{*}{$\mathrm{PPU}_{\mathrm{b}}$} \\
\hline & \multicolumn{11}{|c|}{2005} & \multicolumn{3}{|c|}{2006} & \\
\hline & $\mathrm{F}$ & $\mathrm{M}$ & $\mathrm{A}$ & $\mathrm{M}$ & $\mathrm{J}$ & $\mathrm{J}$ & $\mathrm{A}$ & $\mathrm{S}$ & $\mathrm{O}$ & $\mathrm{N}$ & $\mathrm{D}$ & $\mathrm{J}$ & $\mathrm{F}$ & $\mathrm{M}$ & \\
\hline Fusarium verticillioides & 33.5 & 22.0 & 39.5 & 34.5 & 33.0 & 39.0 & 32.0 & 27.0 & 34.5 & 10.5 & 4.0 & 8.0 & 11.0 & 17.0 & $14 / 24.7$ \\
\hline Fusarium subglutinans & 4.5 & 4.5 & 12.5 & 10.0 & 8.5 & 12.5 & 6.5 & 7.5 & 8.0 & 5.0 & 0.5 & 1.0 & 0.5 & 0.5 & $14 / 5.9$ \\
\hline Fusarium graminearum & 0.0 & 0.0 & 0.0 & 0.0 & 5.0 & 11.0 & 5.0 & 11.0 & 1.0 & 0.5 & 0.0 & 0.0 & 1.5 & 0.0 & $7 / 5.0$ \\
\hline Fusarium proliferatum & 0.0 & 0.0 & 0.0 & 0.0 & 1.0 & 0.0 & 0.0 & 1.0 & 1.5 & 1.5 & 0.0 & 0.0 & 0.0 & 0.0 & $4 / 1.3$ \\
\hline Fusarium sambucinum & 1.0 & 1.0 & 0.0 & 0.0 & 0.0 & 0.0 & 0.0 & 0.0 & 0.0 & 0.0 & 0.0 & 0.0 & 0.0 & 0.0 & $2 / 1.0$ \\
\hline Fusarium poae & 0.0 & 0.0 & 0.0 & 0.0 & 0.5 & 0.0 & 0.0 & 0.0 & 0.0 & 0.0 & 0.0 & 0.0 & 0.0 & 0.0 & $1 / 0.5$ \\
\hline
\end{tabular}

${ }^{\mathrm{a}}$ First letter of month when phytopathological analysis of maize sample stored in the period of February 2005 to March 2006 was carried out.

${ }^{b}$ Number of positive samples of total 14/Average for positive samples 
During the last 20 years, there were no significant changes in the distribution of genera Aspergillus (5.0\%), Fusarium (41.0\%) and Penicillium $(46.0 \%)$ in maize grain in Serbia (Lević et al, 2004), except in the species composition and frequency. Noory (1983) reported the dominance of $F$. oxysporum and a two-fold lower occurrence of $F$. verticillioides (syn. $F$. moniliforme) and F. graminearum, while Lević et al. (2003) detected the dominance of $F$. subglutinans and $F$. verticillioides, the unchanged distribution of $F$. graminearum and the tendency of $F$. proliferatum to spread. In general, these four species can be considered the most important pathogens of maize under agro ecological conditions of Serbia, but with different frequencies over years (Bočarov-Stančić et al., 1997; Lević et al., 1997).

Comparing with Lević et al. (1997), results obtained on stored maize kernels in the period February 2005 to March 2006 show some similarity in dominance of certain species of Fusarium, and also changes in number of isolated species and frequency of particular Fusarium spp. Obtained differences can be interpreted by small number of analyzed samples, different method of sample storing and climatic conditions in which maize was produced and stored.

\section{Conclusions}

Based on investigation of fungi incidence on stored maize grain intended for livestock nutrition, it was determined that during period from February 2005 to March 2006 certain fungal species were present successively (Fusarium spp., Penicillium spp.), others with interruptions of one (Nigrospora spp., Aspergillus spp., Acremonium spp., Alternaria spp), three (Mucor spp., Chaetomium spp., Rhizopus spp.) or four months (Cladosporium spp.), and remaining species sporadically during three (Epicoccum spp., Rhizopus spp., Trichothecium spp.), two (Gliocladium spp.) or one month (Papulaspora spp., Phialophora spp.).

Period June - October was the most critical for preservation of stored maize since the number of present species (8-14 of total 17 identified fungal genera) and frequency of fungi during this period were the highest, especially of toxigenic species of Fusarium (43.5-62.5\%) and Penicillium (10.0-33.5\%) genera.

Positive correlation $\left(\mathrm{r}=0.5979^{* *}\right)$ between dynamics of incidence and frequency of isolated fungi indicates that fungi with higher frequency of incidence remain are maintained longer on maize grain during storage. 
$F$. verticillioides and $F$. subglutinans, of total of six identified Fusarium species were present on grain throughout the year and with the highest frequency $(24.7 \%$ and $5.9 \%$, respectively). During one year (2005) $F$. verticillioides was present in the highest percentage from February to October (22.0-39.5\%), and F. subglutinans from April to October $(6.5-12.5 \%)$, whereas both species were least isolated in winter period December-January (4.0-8.0\% and $0.5-1.0 \%$, respectively). $F$. graminearum is the third toxigenic species of Fusarium genus which from mycotoxicological aspect can be important for period June-September when it is present in the highest percentage $(5.0-11.0 \%)$. Incidence of other species of Fusarium genus is sporadic $(1.3 \% \mathrm{~F}$. proliferatum, $1.0 \% \mathrm{~F}$. sambucinum and $0.5 \% \mathrm{~F}$. poae).

\title{
DINAMIKA POJAVE I UČESTALOSTI POPULACIJA Fusarium VRSTA NA USKLADIŠTENOM ZRNU KUKURUZA
}

\author{
V. Krnjaja, J. Lević, Z. Tomić, Z. Nešić, Lj. Stojanović, S. Trenkovski
}

\section{Rezime}

Proizvodnja i obezbeđivanje visokog kvaliteta zrna kukuruza su od primarnog značaja za stočarsku proizvodnju jer je kukuruz osnovna komponenta stočne hrane. Zaraza gljivama ne samo da smanjuje kvalitet zrna, već neke vrste gljiva mogu produkovati visoko toksična jedinjenja, poznata kao mikotoksini. S obzirom da je kukuruz ekonomski najvažnija gajena biljka u Srbiji, sadržaj i intenzitet učestalosti ovih patogenih vrsta gljiva se ispituje u kukuruzu u skladištu.

$\mathrm{Na}$ osnovu proučavanja pojave gljiva na uskladištenom kukuruzu, koji je bio namenjen za ishranu životinja, utvrđeno je da su u periodu od februara 2005. do marta 2006. godine neke gljive prisutne sukcesivno (Fusarium spp., Penicillium spp.), druge diskontinuirano sa prekidom od jednog (Nigrospora spp., Aspergillus spp., Acremonium spp., Alternaria spp), tri (Mucor spp., Chaetomium spp., Rhizopus spp.) ili četiri meseca (Cladosporium spp.), a treće sporadično u toku tri (Epicoccum spp., Rhizopus spp., Trichothecium spp.), dva (Gliocladium spp.) ili jednog meseca (Papulaspora spp., Phialophora spp.). Period jun-oktobar je 
najkritičniji za očuvanje kvaliteta uskladištenog kukuruza jer je brojnost (prisutno 8-14 od ukupno 17 identifikovanih rodova gljiva) i frekvencija gljiva u tom periodu najveća, posebno toksigenih vrsta iz rodova Fusarium (43.5-62.5\%) i Penicillium (10.0-33.5\%). Pozitivna korelacija $(\mathrm{r}=$ $0.5979^{* *}$ ) između dinamike pojave i frekvencije izolovanih vrsta gljiva ukazuje da se gljive sa većom frekvencijom pojave duže održavaju na zrnu kukuruza tokom skladištenja.

$F$. verticillioides i $F$. subglutinans su od ukupno šest identifikovanih vrsta roda Fusarium prisutne na zrnu tokom cele godine i sa najvećom frekvencijom (24.7\% i 5.9\%). U toku jedne godine (2005) $F$. verticillioides je u najvećem procentu prisutna od februara do oktobra (22.0-39.5\%), a $F$. subglutinans od aprila do oktobra (8.0-12.5\%), dok su obe vrste najmanje izolovane u zimskom periodu decembar-januar (4.0-8.0\% i $0.5-1.0 \%)$. $F$. graminearum je treća toksigena vrsta roda Fusarium koja sa mikotoksikološkog aspekta može biti značajna za period jun-septembar kada se javlja u najvećem procentu (5.0-11.0\%). Pojava ostalih vrsta roda Fusarium je sporadična $(1.3 \% \mathrm{~F}$. proliferatum, $1.0 \% \mathrm{~F}$. sambucinum and $0.5 \%$ F. poae).

\section{References}

BOČAROV-STANČIĆ, A. (1996): Uticaj ekoloških i drugih faktora na rasprostranjenje plesni i mikotoksina u žitaricama i mogućnost njihove dekontaminacije. Doktorska disertacija, Poljoprivredni fakultet, Univerzitet u Novom Sadu, Novi Sad.

BOČAROV-STANČIĆ, A., ŠKRINJAR, M., MAŠIĆ, Z., PAVKOV, S., GOLOŠIN, B. (1997): Natural occurrance of Fusarium spp. fusariotoxins in Yugoslav corn kernels. Cereal Res. Commun. 25: 581.

BURGESS, L.W., SUMMERELL, B.A.,BULLOCK, S., GOTT, K.P. BACKHOUSE, D. (1994): Laboratory Manual for Fusarium Research. Fusarium Research Laboratory, Department of Crop Sciences, University of Sydney and Royal Botanic Gardens, Sydney, pp. 133.

ELLISS, M. B. (1971): Dematiaceous Hyphomycetes. Commonwealth Mycological Institute, Kew, Surrey, England, pp. 608.

HELL, K., CARDWELL, K.F., POEHLING, H. -M. (2003): Relationship between management practices, fungal infection and aflatoxin for stored maize in Benin. J. Phytopathology 151, 690-698.

HOCKING, A. (2003): Microbiological facts and fictions in grain storage. 
(ed., Stored grain in Australia 2003 by Wright, E.J., Webb, M.C., Highley, E.). Proceedings of the Australian Postharvest Technical Conference, Canberra, 25-27 June 2003, 55-58. CSIRO Stored Grain Research Laboratory, Canberra.

KATTA, S.K., CAGAMPANG, A.E., JACKSON, L.S., BULLERMAN, L.B. (1997): Distribution of Fusarium molds and fumonisins in dry-milled corn fractions. Cereal Chem. 74 (6), 858-863.

LAZAREVIĆ, R., et al. (1998): Program razvoja stočarstva u Republici Srbiji. Biotehnologija u stočarstvu, posebna edicija, pp.53.

LEVIĆ, J., IVANOVIĆ, D., STANKOVIĆ, S. (2003): Seed-borne parasites of maize, sorghum and pearl millet and control measures (in Serbian). Biljni lekar 6: 570-577.

LEVIĆ, J., STANKOVIĆ, S., BOČAROV-STANČIĆ, A. (2004): Pojava i suzbijanje toksigenih vrsta gljiva u uskladištenom žitu. Biljni lekar/Plant Doctor, XXXII, (3-4), 245-254.

LEVIĆ, J., TAMBURIĆ-ILINČIĆ, LJ., PETROVIĆ, T. (1997): Maize kernel infection by Fusarium species in the period 1994-1996. Cereal Res. Commun. 25 (3): 773-775.

LOGRIECO, A., MORETTI, A., RITIENI, A., BOTTALICO, A., CORDA, P. (1995): Occurence and toxigenicity of Fusarium proliferatum from preharvest maize ear rot and associated mycotoxins in Italy. Plant Dis, 727731.

MARASAS, W.F.O. (1991): Toxigenic Fusaria. Mycotoxins and Animal Foods, ed. By John E. Smith and Rachel S. Hendersen (London: CRC Press, Inc.), pp. 119-139.

MARASAS, W.F.O. (2000): Fusarium mycotoxins in the third millennium. The $6^{\text {th }}$ European Fusarium Seminar and Third COST 835 Workshop of Agriculturally Important Toxigenic Fungi, Berlin (Germany), 11-16 September, 2000, 42.

MARASAS, W.F.O., KRIEK, N.P.J., WIGGONS, P.S., TOWERS, D.K. (1979): Incidence, geographical distribution, the toxigenicity of Fusarium species in South Africa corn. Phytopathology, 69, 11181-1185.

MARASAS, W.F.O., NELSON, P.E., TOUSSOUN, T.A. (1984): Toxigenic Fusarium species. Identity and Mycotoxicology. The Pennsylvania State University Press University Park and London, 328.

MARIĆ, A. (2002): Bolesti tipa plesnivosti (truleži) klipa i zrna. Kolektiv autora (ed.), Bolesti, štetočine i korovi kukuruza i njihovo suzbijanje, DOO "Školska knjiga", Novi Sad, 111-127.

MUNKVOLD, G.P. (2003): Epidemiology of Fusarium diseases and their 
mycotoxins in maize ears. Eur J Plant Pathol (109), 705-713.

NELSON, P. E., TOUSSOUN,T.A., MARASAS, W.F.O. (1983): Fusarium Species, an Illustrated Manual for Identification. The Pennsylvania State University Press, University Park and London, pp. 133.

NOORY, M.J. (1983): Mycopopulations in corn grains and sunflower seeds, and toxicity of Aspergillus and Fusarium species isolated from these products. Ph.D. Thesis. University of Belgrade, Faculty of Sciences, Belgrade, 184.

OLIVEIRA, G.R., RIBEIRO, J.M., FRAGA, M.E., CAVAGLIERI, L.R., DIREITO, G.M., KELLER, K.M., DALCERO, A.M., ROSA, C.A. (2006): Mycobiota in poultry feeds and natural occurrence of aflatoxins, fumonisins and zearalenone in the Rio de Janeiro State, Brazil.

POZZI, C.R., B. CORRÊA, W. GAMBALE, C. R. PAULA, N. O. CHACON-RECHE, M. C. A. MEIRELLES (1995): Postharvest and stored corn in Brazil: mycoflora interaction, abiotic factors and mycotoxin occurrence. Food Additives and Contaminants, Vol. 12, No. 3, 313-319.

STATISTICAL YEARBOOK OF SERBIA/ STATISTIČKI GODIŠNJAK SRBIJE (2001): Republika Srbija. Republički Zavod za informatiku i statistiku. Beograd, decembar 2001, Godina 34, pp. 461.

TENUTA, A. (2006): Identifying corn ear molds. www.omafra.gov.on.ca/english/crops/field/news/croppest/2006/17cpo06a1.h tm

VISCONTI, A., DOKO M.B. (1994): Survey of fumonisin production by Fusarium isolated from cereals in Europe. J Assoc Offic Anal Chem (77), 546-550.

WATANABE, T. (1994): Pictorial atlas of soil and seed fungi. In: Morphologies of cultured fungi and key to species. Lewis Publishers, Boca Raton, Boston, London, Washington D.C., pp. 410.

WHITE, G.D. (2000): Compendium of corn diseases, $3^{\text {rd }}$ ed. St. Paul MN: APS Press, $78 \mathrm{pp}$. 